\title{
A closeup study of early beech litter decomposition: potential drivers and microbial interactions on a changing substrate
}

\author{
Christian Brandstätter • Katharina Keiblinger • \\ Wolfgang Wanek • Sophie Zechmeister-Boltenstern
}

Received: 30 May 2012 / Accepted: 28 February 2013 /Published online: 17 March 2013

(C) The Author(s) 2013. This article is published with open access at Springerlink.com

\begin{abstract}
Aims Litter decomposition and subsequent nutrient release play a major role in forest carbon and nutrient cycling. To elucidate how soluble or bulk nutrient ratios affect the decomposition process of beech (Fagus sylvatica L.) litter, we conducted a microcosm experiment over an 8 week period. Specifically, we investigated leaf-litter from four Austrian forested sites, which varied in elemental composition ( $\mathrm{C}: \mathrm{N}: \mathrm{P}$
\end{abstract}

Responsible Editor: Stefano Manzoni.

C. Brandstätter

BFW - Federal Research and Training Centre for Forests, Natural Hazards and Landscape,

Seckendorff-Gudent Weg 8,

1131 Vienna, Austria

K. Keiblinger $\cdot \mathrm{S}$. Zechmeister-Boltenstern

Institute of Soil Research, University of Natural Resources

and Life Sciences,

Peter-Jordan-Straße 82,

1190 Vienna, Austria

W. Wanek

CHECO - Institute of Chemical Ecology and Ecosystem

Research, University of Vienna,

Althanstraße 14,

1090 Vienna, Austria

C. Brandstätter $(\bowtie)$

Institute for Water Quality, Resources and Waste

Management, Vienna University of Technology,

Karlsplatz 13/226,

1040 Vienna, Austria

e-mail: bran.chri@gmail.com ratio). Our aim was to gain a mechanistic understanding of early decomposition processes and to determine microbial community changes.

Methods We measured initial litter chemistry, microbial activity in terms of respiration $\left(\mathrm{CO}_{2}\right)$, litter mass loss, microbial biomass $\mathrm{C}$ and $\mathrm{N}\left(\mathrm{C}_{\text {mic }}\right.$ and $\left.\mathrm{N}_{\text {mic }}\right)$, non purgeable organic carbon (NPOC), total dissolved nitrogen (TDN), $\mathrm{NH}_{4}{ }^{+}, \mathrm{NO}_{3}{ }^{-}$and microbial community composition (phospholipid fatty acids - PLFAs).

Results At the beginning of the experiment microbial biomass increased and pools of inorganic nitrogen $(\mathrm{N})$ decreased, followed by an increase in fungal PLFAs. Sites higher in NPOC:TDN (C:N of non purgeable organic $\mathrm{C}$ and total dissolved $\mathrm{N}$ ), $\mathrm{K}$ and Mn showed higher respiration.

Conclusions The C:N ratio of the dissolved pool, rather than the quantity of $\mathrm{N}$, was the major driver of decomposition rates. We saw dynamic changes in the microbial community from the beginning through the termination of the experiment.

Keywords Leaf litter decomposition · Microbial biomass $\cdot$ Microcosm $\cdot$ Microbial community structure analysis · Microbial respiration

$\begin{array}{ll}\text { Abbreviations } \\ \mathrm{AK} & \text { Achenkirch } \\ \mathrm{C} & \text { Carbon } \\ \mathrm{Ca} & \text { Calcium } \\ \mathrm{C}_{\text {mic }} & \text { Microbial biomass carbon } \\ \mathrm{C}_{\text {mic }}: \mathrm{N}_{\text {mic }} & \mathrm{C}: \mathrm{N} \text { microbial biomass }\end{array}$




$\begin{array}{ll}\text { DOC } & \text { Dissolved organic carbon } \\ \text { dw } & \text { Dry weight } \\ \text { ECD } & { }^{63} \text { Ni-electron-capture detector } \\ \text { FB-ratio } & \text { Fungal-bacterial ratio } \\ \text { Fe } & \text { Ferrum } \\ \text { FID } & \text { Flame ionisation detector } \\ \mathrm{K} & \text { Potassium } \\ \mathrm{K} & \text { Decomposition constant } \\ \mathrm{KL} & \text { Klausen-Leopoldsdorf } \\ \mathrm{Mg} & \text { Magnesium } \\ \mathrm{ML} & \text { Litter mass loss } \\ \mathrm{N} & \text { Nitrogen } \\ \mathrm{N} \text { mic } & \text { Microbial biomass nitrogen } \\ \text { NPOC } & \text { Non purgeable organic carbon } \\ \text { OR } & \text { Ort } \\ \mathrm{P} & \text { Phosphorus } \\ \text { PE } & \text { Perg } \\ \text { PC } & \text { Principal component } \\ \text { PCA } & \text { Principal component analysis } \\ \text { PLFA } & \text { Phospholipid fatty acid } \\ \text { qCO2 } & \text { Microbial metabolic quotient } \\ \text { NPOC:TDN } & \text { C:N ratio of non purgeable organic } \\ & \text { C and total dissolved N } \\ \text { TDN } & \text { Total dissolved nitrogen } \\ \text { TIN } & \text { Total inorganic nitrogen } \\ \text { Zn } & \text { Zinc } \\ & \end{array}$

\section{Introduction}

Climate and substrate quality are the main drivers of leaf litter decomposition rates (Meentemeyer 1978; Prescott 1995). Specifically, the chemical composition of litter (e.g. lignin- and N-content) has been shown to strongly affect decomposition rates (Melillo et al. 1982; Prescott 2010). Usually, to assess litter decomposition rates two basic methods are used: the litter bag-technique or microcosm studies (Salamanca et al. 1998). In the present study, we controlled variation of climatic factors to a minimum by using the microcosm approach (Taylor et al. 1989), which allowed us to more exclusively focus on the impact of substrate quality and initial nutrient stoichiometry on decomposition. Even though increasing numbers of studies have dealt with decomposition rates in early stages (Prescott 2010), we propose that the importance of the dynamics of the early stages of decomposition has been widely overlooked. In the present study we more explicitly explore the time course of very early litter decomposition. The chosen high temporal resolution allowed us to find new insight into the very early microbial and nutrient dynamics in a leaf litter system.

Initial litter composition is thought to control litter decomposition rates (Jacob et al. 2010) as well as initial nutrient content and relative amounts of labile and refractory carbon (C) (Aber and Melillo 1991; Melillo et al. 1982). During the early phase, C is relatively available and nutrients are often a limiting factor, since immobilization of the limiting nutrient (usually N) occurs regularly (Prescott 2005). Litter with greater initial $\mathrm{N}$ content has been shown to decompose at a faster rate because it poses a smaller discrepancy in the $\mathrm{C}: \mathrm{N}$ ratio between litter and decomposer microbes, and so microbes will need to immobilize less $\mathrm{N}$ to decompose the litter (Aber and Melillo 1991).

During litter decomposition the $\mathrm{C}$ pool is subject to qualitative changes: easily accessible substances like cellulose and C-containing cell solubles are preferably decomposed, which leads to an increase in more recalcitrant $\mathrm{C}$-containing molecules like lignin and lignified cellulose and a slowing of the decomposition rate (Berg 2000; Berg et al. 1993). The impact of $\mathrm{N}$ on decomposition is more controversial. So far, the classification of the time into "short-term" and "longterm" litter decomposition is relatively common (Berg and McClaugherty 2008). Nitrogen (N) seems to accelerate decomposition in earlier stages due to a higher microbial nutrient demand (Moorhead and Sinsabaugh 2006), whereas in later stages it is thought to decelerate litter decomposition (Gallo et al. 2004). This issue has been addressed as "microbial mining theory" (Craine et al. 2007). In a recalcitrant substrate, certain guilds of microbes have to invest more energy and therefore be able to access nutrients that are closely tied to the substrate. If enough $\mathrm{N}$ is available, there is no need to decompose recalcitrant substances to access nutrients, thus decomposition slows down despite high $\mathrm{N}$-availability.

Other possible mechanisms for the inhibition of late stage decomposition by $\mathrm{N}$ additions include a proposed negative effect of $\mathrm{N}$ on $\mathrm{C}$ mineralization, or a negative effect on lignin degradation by inhibiting lignin degrading enzymes, resulting in reduced availability of the structural carbohydrates in the lignocellulose complex (Chesson et al. 1997; Henriksen and Breland 1999). 
In addition to the abundant $\mathrm{C}$ and $\mathrm{N}$, other elements have been discussed to be able to control litter decomposition, mainly $\mathrm{Mn}$ and $\mathrm{P}$. In general, litter poor in $\mathrm{P}$ is suggested to have higher $\mathrm{F} / \mathrm{B}$ ratios (Hieber and Gessner 2002; van der Wal et al. 2006; Güsewell and Gessner 2009). A previous study at these same sites as the current study has noted a strong impact of $\mathrm{P}$ on the microbial community composition (Schneider et al. 2012) and another one on the early phases of litter decomposition at other sites (Aerts and de Caluwe 1997). Similarly, Mn has been mentioned in relation to fungal decomposition, as fungi use Mn-peroxidaseenzymes for lignin degradation (Hofrichter 2002). Fungi have the ability to degrade highly recalcitrant compounds like lignin by excreting extracellular enzymes (Boer et al. 2006). Although with PLFAanalysis it is not possible to distinguish between different fungal phyla, predominant fungal phyla in the soil-litter interface (Osono and Takeda 2006), are considered to be Ascomycota and Basidiomycota. While Ascomycota have been mentioned as first colonizers during beech litter decomposition at similar Austrian sites (Schneider et al. 2012), they are regarded primarily as cellulose decomposers or sugar fungi (Osono 2007) and their ability to degrade lignin is limited. On the other hand, the succession at later stages of decomposition tends towards Basidiomycota at these same Austrian sites (Schneider et al. 2012), which have previously been shown to be controlled by the Mn content of the original litter (Berg et al. 2007). Within the decomposer community fungi and bacteria exhibit different nutrient demands and constraints on the decomposition processes, (Keiblinger et al. 2012), and thereby influence decomposition including the $\mathrm{C}$ use efficiency (Sinsabaugh et al. 2009; Keiblinger et al. 2010).

In the current study we asked: (i) Would higher initial $\mathrm{N}$ content and lower $\mathrm{C}: \mathrm{N}$ ratios accelerate early stage decomposition rates (Schneider et al. 2012; Zhang et al. 2008) of lignin-rich (Melillo et al. 1982) and thus recalcitrant beech litter (Mungai and Motavalli 2006)? (ii) Which other elements in addition to, or beside, $\mathrm{N}$ possibly influenced the decomposition rates of beech litter? (iii) How would the litter decomposing microbial community react to changes in substrate quality during the early stage of decomposition?

To answer these questions, we closely examined nutrient sinks and sources, respiration and microbial community composition weekly over the course of the 8 week experiment. We also focused on interactions between fungi and bacteria in relation to changes in substrate quality, as for terrestrial litter decomposition fungal/bacterial interaction studies (e.g. Rousk and Baath 2007; Schneider et al. 2010) are not as well investigated as in comparison for aquatic litter decomposition (Das et al. 2007; Mille-Lindblom and Tranvik 2003; Schlief and Mutz 2007).

\section{Material and methods}

Sample sites

In autumn 2007 we collected fresh beech (Fagus sylvatica L. (1753)) litter from the surface of the forest floor from four different sites in Austria: Achenkirch, Tyrol (AK), Klausen-Leopoldsdorf, Lower Austria (KL), Perg, Upper Austria (PE) and Ort, Gmunden, Upper Austria (OR), which varied in elemental nutrient stoichiometry. Achenkirch is a Tyrolean SpruceBeech (Picea abies L., H.KARST. (1881)) forest on Rendric Cambisol with a $\mathrm{pH}$ of 7.0. The coordinates of $\mathrm{AK}$ are $47^{\circ} 35^{\prime} \mathrm{N}$ and $11^{\circ} 39^{\prime} \mathrm{E}$ (Ambus et al. 2006). Klausen-Leopoldsdorf is situated in the Vienna Woods, with the coordinates $48^{\circ} 07^{\prime} \mathrm{N}$ and $16^{\circ} 03^{\prime} \mathrm{E}$. The soil type is Dystric Cambisol with a $\mathrm{pH}$ of 4.6 (Kitzler et al. 2006b). The coordinates of OR are $47^{\circ}$ $51^{\prime} \mathrm{N}$ and $13^{\circ} 42^{\prime} \mathrm{E}$. The forest consists mostly of beech but also of Norway spruce and fir (Abies alba MILL. (1768)). The soil is a Dystric Cambisol on carbonate rock. The coordinates of PE are $14^{\circ} 54^{\prime} \mathrm{N}$ and $48^{\circ} 21^{\prime} \mathrm{E}$. The site is dominated by beech, but it also contains conifers (Picea abies, also Abies alba) and the soil type is Cambisol (eBOD, BFW, Austria, based on the digital soil map of Austria, $1 \mathrm{~km}$-grid).

\section{Experimental setup}

Before being put into microcosms, the air-dried beech litter was shredded and sieved with only the fraction from $1 \mathrm{~mm}^{2}$ to $1 \mathrm{~cm}^{2}$ included in the experiment. Every microcosm consisted of a PVC cylinder $(\varnothing 10 \times 10 \mathrm{~cm}$ height) with a grate two $\mathrm{cm}$ above the bottom. Before the start of the experiment, dry litter was re-wetted with deionized water to reach a water content of $60 \%$ and left to equilibrate for 2 days. Into each microcosm $38 \mathrm{~g}$ of moist litter were then filled and incubated at $20 \pm 2{ }^{\circ} \mathrm{C}$. Water content was adjusted weekly. To prevent drying, the microcosms were 
covered with a perforated polyethylene foil fixed to a two $\mathrm{cm}$ ring of drainage pipe and a moist sponge cloth was laid underneath. After destructive sampling of the microcosms the litter was chopped into small pieces with a two-bladed mincing knife and homogenized.

In total 60 microcosms, 15 for litter from each site were established. Every week respective samples were taken out of one single cylinder, with three exceptions: in week zero samples were gathered from the original litter pool $(n=1)$. In week four, four microcosms $(n=4)$, and in week eight five $(n=5)$ microcosms were available. This approach resulted in an unbalanced statistical design.

The number of subsamples for the used methods is given at the respective section. Gas sampling was conducted every week in four separate microcosms per site. At week eight these microcosms also were analysed for $\mathrm{NH}_{4}^{+}, \mathrm{NO}_{3}^{-}$, microbial biomass $\mathrm{C}$ $\left(\mathrm{C}_{\text {mic }}\right)$ and $\mathrm{N}\left(\mathrm{N}_{\text {mic }}\right)$ and PLFAs. PLFA analyses were conducted three times during this 8-week experiment, whereas all other analyses were performed weekly.

Elemental analyses

Ten $\mathrm{g}$ of fresh litter from every cylinder was oven dried overnight at $105{ }^{\circ} \mathrm{C}$ and milled to a fine powder to obtain homogenous samples. Prior to the start of the experiment an elemental analysis of the collected litter with six subsamples per site was performed. The milled samples were wet oxidized $\left(\mathrm{H}_{2} \mathrm{SO}_{4}+\mathrm{HNO}_{3}\right)$ in a microwave oven (Henschler 1988) and elements (P, K, Ca, Mg, Fe, Mn, Zn) were determined by inductively coupled plasma atomic emission spectrometry (ICP-AES). Carbon and N-contents were measured with a Leco CN2000 elemental analyzer (LECO corp. St Joseph, MI, USA) initially and during the experiment for every microcosm.

\section{Gas fluxes}

Microcosms were opened $2 \mathrm{~min}$ before gas sampling. Two airtight covers were then used for gas sampling, one with a hole and a septum sealed by means of silicone (Baysilone medium viscous; Bayer corp., Leverkusen, Germany) to the top of the microcosm. A $2 \mathrm{~mm}$ polyurethane band was adjusted inside the covers and parafilm outside for air-tight sealing. After sealing the microcosms we sampled $10 \mathrm{ml}$ headspace air of the gas tight microcosms. Over a time course of $20 \mathrm{~min}$ gas samples were taken every five minutes and gas samples were analysed by gas-chromatography with a $6890 \mathrm{~N}$ GCSystem (Agilent, Santa Clara, CA, USA) connected to an automatic headspace-sample injection system (Dani HSS 86.50 Dani, Cologno Monzese, Italy). Measurements and calculations of $\mathrm{CO}_{2}$ and $\mathrm{N}_{2} \mathrm{O}$ were conducted as described by Kitzler et al. (2006a), and of $\mathrm{CH}_{4}$ as in Schaufler et al. (2010).

$\mathrm{NH}_{4}{ }^{ \pm} / \mathrm{NO}_{3}{ }^{-}, \mathrm{C}_{\text {mic }}$ and $\mathrm{N}_{\text {mic }} ; \mathrm{NPOC}$ and TDN-measurement

Litter was extracted in two subsamples per microcosm in a $1: 20 \mathrm{w} / \mathrm{v}$ ratio in $0.1 \mathrm{M} \mathrm{KCl}$-solution shaking at vigorous agitation for $1 \mathrm{~h}$ for analyses of $\mathrm{NO}_{3}{ }^{-}$and $\mathrm{NH}_{4}{ }^{+}$which were conducted according to Kandeler (1996) with minor modifications, and detected with a MQuant mQx200 well plate reader (Bio-Tek Instruments, Inc., Vermont, USA) at a wavelength of $660 \mathrm{~nm}$ for $\mathrm{NH}_{4}{ }^{+}$and $210 \mathrm{~nm}$ for $\mathrm{NO}_{3}{ }^{-}$. The determination of $\mathrm{N}_{\text {mic }}$ and $\mathrm{C}_{\text {mic }}$ was performed from two subsamples per microcosm via chloroform fumigation extraction (Öhlinger 1996). An extractability factor was not applied for calculation of microbial biomass. Non purgeable organic C (NPOC) and total dissolved $\mathrm{N}(\mathrm{TDN})$ were determined from a 1:20 w/v extract in $1 M \mathrm{KCl}$ with a TOC/TN analyser (TOC-V CPH E200V, linked with a TN-unit TNM-1 $220 \mathrm{~V}$, Shimadzu Corporation, Kyoto, Japan). Sample extracts were stored frozen at $-20{ }^{\circ} \mathrm{C}$ prior to analysis.

\section{Phospholipid fatty acids PLFA}

Phospholipid fatty acid analyses were performed at three time points (initially out of the litter pool $(n=1)$, after four $(n=4)$ and 8 weeks $(n=5)$. For every PLFA analysis, three subsamples were extracted from $1 \mathrm{~g}$ subsamples using a modified Bligh and Dyer technique, as described by Hackl et al. (2005), referring to Frostegard et al. (1991) and detected with a FID on a HP 6890 Series GC-System and a 7683 Series injector and auto sampler on a HP-5 capillary column. For identification of the fatty acid methyl esters an external standard (Bacterial acid methyl esters mix from SUPELCO, St. Louis, Missouri, USA) was used. For quantification of the peaks methyl non-adecanoate fatty 
acid (19:0) was added as internal standard. The GCinjection volume was $0.2 \mu \mathrm{l}$. PLFA nomenclature is based upon Frostegard et al. (1993). The PLFAs i14:0, i15:0, a15:0, i16:0, i17:0, a17:0 were chosen to represent gram + bacteria. The PLFAs 16:1 $\omega 7,16: 1 \omega 9$,

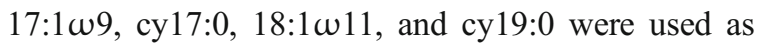
biomarkers of gram- bacteria (Fierer et al. 2003). 18:2w6 was regarded as fungal marker (Zelles 1997) and 10Me16:0, 10Me17:0 and 10Me18:0 were applied as biomarkers of actinomycetes (Frostegard et al. 1993). 14:0, 15:0 and 17:0 were for unspecific bacteria. The sum of markers for gram+, gram- and unspecific bacteria accounted for total bacteria. The ratio fungal/bacterial PLFA was calculated with 18:2w6 divided through the amount of bacterial PLFA (Frostegard and Baath

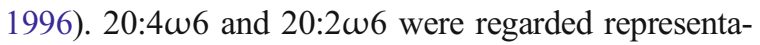
tive of protozoa (White et al. 1996).

\section{Statistical analyses}

One-way ANOVAs followed by Tukey's HSD test were used to evaluate differences between litter from the four sites. The program used for most of the graphs, regressions and non-parametric Spearman correlations was R 2.9.0 (R_Development_Core_Team 2009). ANOVAs and Pearson correlations of normally distributed data were carried out with STATGRAPHICS Centurion XV (StatPoint Technologies, Virginia, USA). Where a prerequisite for ANOVA in terms of homogeneity of variance was violated, as tested by Levene's test, nonparametric Kruskal-Wallis tests were calculated. Two principal component analyses (PCA) were calculated with and without PLFA results using the program SIMCA-P 11.0 (Umetrics, Umeå, Sweden).

\section{Results}

Litter elemental composition

Beech litter from the four sites significantly differed in nutrient stoichiometry $(\mathrm{C}: \mathrm{N}, \mathrm{C}: \mathrm{P}, \mathrm{N}: \mathrm{P})$ and in nutrient content for certain elements $(\mathrm{P}, \mathrm{K}, \mathrm{Mg}, \mathrm{Mn})$ as shown in Table 1. Initial C:N-ratios ranged from average 48.7 (AK) to 57.6 (PE) with significant differences between OR, PE and either AK or KL. The C:N-ratios significantly decreased over time in litter from the four sites from 51.8 at week zero to 47.0 at week eight. For single sites, no significant differences were found between the weeks. Averaged over the whole experiment, the highest C:N-ratio was found for PE (51.4), followed by OR (50.3), KL (46.9) and AK (43.9).

Total $\mathrm{N}$ content was highest in AK $(1.17 \%)$ and lowest in litter from PE $(0.93 \%)$ for the duration of the experiment. The initial Mn-, Ca-, P-, and Kcontents were significantly different for all sites (Table 1). The initial K-content was highest in KL (0.395 $\left.\mathrm{mg} \mathrm{kg}^{-1}\right)$, followed by PE, OR and AK

Table 1 Initial beech litter chemistry of four different sites

\begin{tabular}{llcccc}
\hline & & AK & KL & OR & PE \\
\hline $\mathrm{C}$ & $(\%)$ & $50.94^{\mathbf{c}}(0.04)$ & $49.42^{\mathbf{b}}(0.18)$ & $48.65^{\mathbf{a}}(0.14)$ & $49.59^{\mathbf{b}}(0.16)$ \\
$\mathrm{N}$ & $(\%)$ & $1.05^{\mathbf{c}}(<0.01)$ & $0.97^{\mathbf{b}}(<0.02)$ & $0.90^{\mathbf{a}}(<0.01)$ & $0.86^{\mathbf{a}}(<0.02)$ \\
$\mathrm{P}$ & $(\%)$ & $0.030^{\mathbf{a}}(<0.001)$ & $0.033^{\mathbf{b}}(<0.001)$ & $0.045^{\mathbf{c}}(<0.001)$ & $0.056^{\mathbf{d}}(<0.001)$ \\
$\mathrm{K}$ & $(\%)$ & $0.099^{\mathbf{a}}(0.002)$ & $0.395^{\mathbf{d}}(0.003)$ & $0.179^{\mathbf{b}}(0.002)$ & $0.212^{\mathbf{c}}(0.002)$ \\
$\mathrm{Ca}$ & $(\%)$ & $1.48^{\mathbf{c}}(0.02)$ & $1.30^{\mathbf{b}}(0.02)$ & $2.03^{\mathbf{d}}(0.02)$ & $1.16^{\mathbf{a}}(0.01)$ \\
$\mathrm{Mg}$ & $(\%)$ & $0.23^{\mathbf{d}}(<0.01)$ & $0.16^{\mathbf{b}}(<0.01)$ & $0.16^{\mathbf{c}}(<0.01)$ & $0.13^{\mathbf{a}}(<0.01)$ \\
$\mathrm{Fe}$ & $\left(\mathrm{mg} \mathrm{kg}^{-1}\right)$ & $121.9^{\mathbf{a}}(3.7)$ & $175.5^{\mathbf{b}}(4.5)$ & $240.9^{\mathbf{c}}(16.8)$ & $181.5^{\mathbf{b}}(8.5)$ \\
$\mathrm{Mn}$ & $\left(\mathrm{mg} \mathrm{kg}^{-1}\right)$ & $103.8^{\mathbf{a}}(2.6)$ & $985.2^{\mathbf{d}}(18.3)$ & $521.2^{\mathbf{c}}(19.0)$ & $292.8^{\mathbf{b}}(9.4)$ \\
$\mathrm{Zn}$ & $\left(\mathrm{mg} \mathrm{kg}^{-1}\right)$ & $32.3^{\mathbf{a}}(0.9)$ & $39.0^{\mathbf{b}}(1.6)$ & $34.1^{\mathbf{a}}(0.6)$ & $41.2^{\mathbf{b}}(0.8)$ \\
$\mathrm{C}: \mathrm{N}$ & & $48.7^{\mathbf{a}}(0.3)$ & $50.9^{\mathbf{a}}(0.7)$ & $54.2^{\mathbf{b}}(0.4)$ & $57.6^{\mathbf{c}}(0.8)$ \\
$\mathrm{C}: \mathrm{P}$ & & $1707^{\mathbf{d}}(18)$ & $1494^{\mathbf{c}}(34)$ & $1090^{\mathbf{b}}(16)$ & $892^{\mathbf{a}}(2)$ \\
$\mathrm{N}: \mathrm{P}$ & & $35.0^{\mathbf{d}}(0.2)$ & $29.1^{\mathbf{c}}(0.4)$ & $20.1^{\mathbf{b}}(0.2)$ & $15.8^{\mathbf{a}}(0.2)$ \\
\hline
\end{tabular}

Values represent means, with $+/-\mathrm{SE}$ in parentheses, different letters indicate significant differences between sites after Tukey's HSD test $(p<0.05, n=6)$

$A K$ Achenkirch, KL Klausen-Leopoldsdorf, OR Ort and PE Perg 
(0.099 $\left.\mathrm{mg} \mathrm{kg}^{-1}\right)$. Initial Ca-content was highest in litter from OR $(2.03 \%)$ and lowest for PE $(1.16 \%)$ and $\mathrm{P}$ was highest in PE $(0.056 \%)$ and lowest in AK $(0.03 \%)$. Manganese was highest in KL (985.2 mg $\mathrm{kg}^{-1}$ ), followed by OR, PE and AK (103.8 $\left.\mathrm{mg} \mathrm{kg}^{-1}\right)$.

Litter mass loss (ML)

Final mass loss was significantly highest with $8.8 \%$ in $\mathrm{KL}$, the site with highest respiratory activity, with $6.6 \%$ in OR, $6.9 \%$ in PE and $7.1 \%$ in AK (Fig. 1a) without significant differences between these three other sites. The cumulative mass loss between week 0 and 1 was slightly negative. This can possibly be contributed to the fact, that watering during the experiment was applied 1 day before the harvesting procedure and thus could have slightly increased the weight of the microcosms. The calculated cumulative C-loss obtained by gravimetric method at week eight ranged between $30.7 \mathrm{mg} \mathrm{C} \mathrm{g}^{-1}$ DW (OR) and $43.9 \mathrm{mg} \mathrm{C} \mathrm{g}^{-1} \mathrm{DW}(\mathrm{KL})$.

$\mathrm{NH}_{4}{ }^{ \pm}$and $\mathrm{NO}_{3}{ }^{-}$-concentrations

Initial $\mathrm{NH}_{4}{ }^{+}-\mathrm{N}$ concentration was highest in $\mathrm{AK}$ and lowest in $\mathrm{KL}$, decreased in the first weeks and remained at a low level during the later stage of the experiment (Table 2, Fig. 1b,). Generally $\mathrm{NO}_{3}^{-}$decreased in the beginning and started to increase after 6 weeks (Table 2). The site highest in respiration (KL) revealed lowest initial $\mathrm{NH}_{4}^{+}$concentrations but highest concentrations of $\mathrm{NO}_{3}{ }^{-}$. Total inorganic $\mathrm{N}\left(\mathrm{NH}_{4}{ }^{+}+\right.$ $\mathrm{NO}_{3}{ }^{-}$, TIN, Table 2, Fig. 1c) declined over time with an initial average of $425 \mu \mathrm{g} \mathrm{N} \mathrm{g}^{-1} \mathrm{dw}$ to $66.1 \mu \mathrm{g} \mathrm{N} \mathrm{g}^{-1}$ $\mathrm{dw}$ at week eight, and it was generally highest for microcosms of OR $\left(465 \mu \mathrm{g} \mathrm{N} \mathrm{g}^{-1} \mathrm{dw}\right.$ to $116 \mu \mathrm{g} \mathrm{N}$ $\left.\mathrm{g}^{-1} \mathrm{dw}\right)$.

\section{Gas fluxes}

Respiration declined during the experiment (Fig. 1d) with highest initial values in $\mathrm{KL}\left(104.4 \mu \mathrm{g} \mathrm{C} \mathrm{g}^{-1} \mathrm{dw}\right.$ $\mathrm{h}^{-1}$ ). During most of the experiment respiration was significantly higher in KL than in litter from the other sites and AK was lowest. Respiration showed the opposite pattern than initial $\mathrm{NH}_{4}{ }^{+}$concentration between sites ( $\mathrm{KL}>\mathrm{PE}>\mathrm{OR}>\mathrm{AK}$ ). During the experiment there was no significant $\mathrm{N}_{2} \mathrm{O}$ and $\mathrm{CH}_{4}$ production and/or consumption.

The cumulative $\mathrm{C}$-loss after 8 weeks via respiration showed values between $234 \mathrm{mg}$ (AK) and $631 \mathrm{mg}$
Fig. 1 Time course of a) Mass Loss \%, b) $\mathrm{NH}_{4}{ }^{+}-\mathrm{N}$, c) total inorganic $\mathrm{N}(T I N)$ and d) respiration. An ANOVA was conducted for week 4 and 8 to detect significant differences between the four sites. Where brackets indicate a violation of the prerequisite of homogenous variances, a non-parametric Kruskal-Wallis test was computed (ns $p>0.05 ; * p<$ 0.05 ; ** $p<0.01$; *** $p<$ 0.001). $A K$ Achenkirch, $K L$ Klausen-Leopoldsdorf, $O R$ Ort, PE Perg
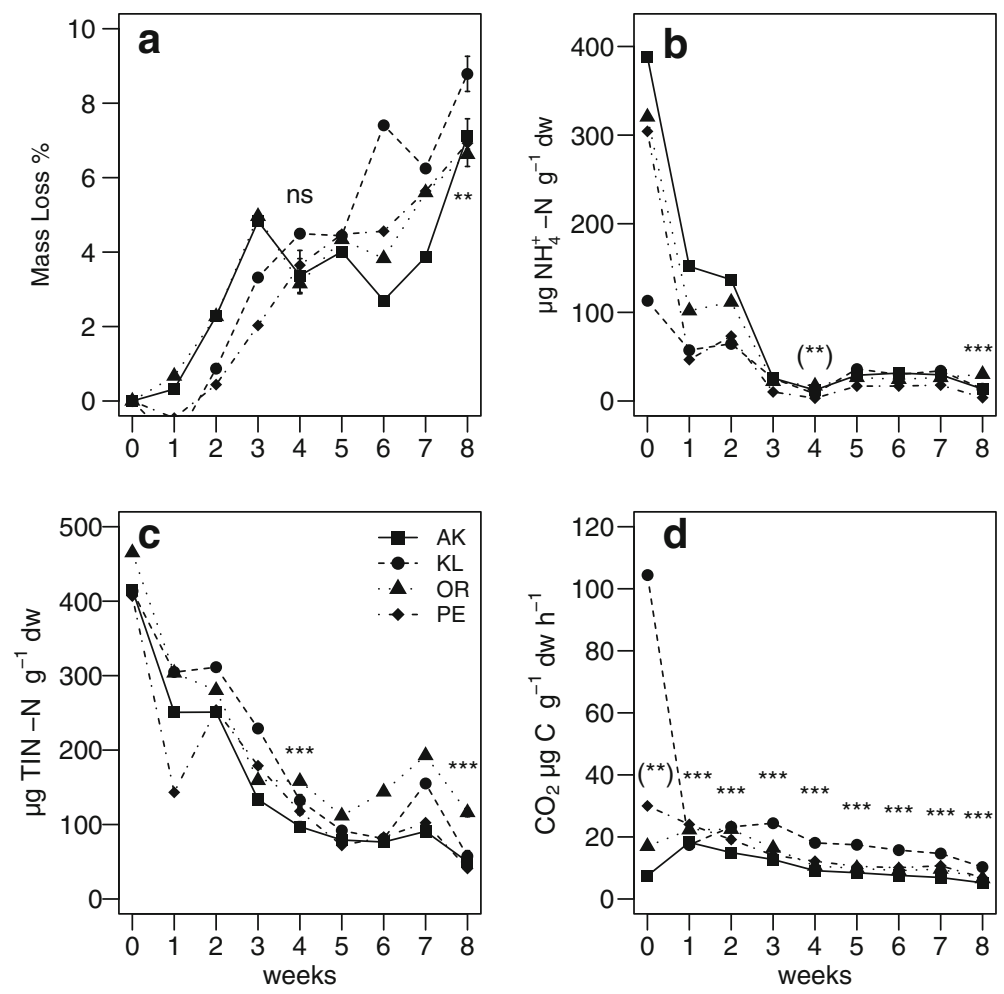
Table 2 Nitrogen and carbon pools averaged over all four sites during 8 weeks

\begin{tabular}{|c|c|c|c|c|c|c|c|c|c|}
\hline Weeks & $\mathrm{N}$ & $\mathrm{C}$ & $\mathrm{NH}_{4}^{+}$ & $\mathrm{NO}_{3}^{-}$ & TIN & NPOC & TDN & $\mathrm{C}_{\text {mic }}$ & $\mathrm{N}_{\text {mic }}$ \\
\hline 0 & $\begin{array}{l}150.8 \\
(4.3)\end{array}$ & $\begin{array}{l}7421 \\
(66)\end{array}$ & $\begin{array}{l}4.22 \\
(0.44)\end{array}$ & $\begin{array}{l}2.16 \\
(0.43)\end{array}$ & $\begin{array}{l}6.38 \\
(0.10)\end{array}$ & $\begin{array}{l}147.6 \\
(3.6)\end{array}$ & $\begin{array}{l}16.33 \\
(0.98)\end{array}$ & $\begin{array}{l}18.64 \\
(2.67)\end{array}$ & $\begin{array}{l}1.22 \\
(0.26)\end{array}$ \\
\hline$(\%)$ & 100 & 100 & 2.80 & 1.43 & 4.23 & 1.99 & 10.83 & 0.25 & 0.81 \\
\hline 1 & $\begin{array}{l}155.3 \\
(4.9)\end{array}$ & $\begin{array}{l}7607 \\
(130)\end{array}$ & $\begin{array}{l}1.37 \\
(0.19)\end{array}$ & $\begin{array}{l}2.47 \\
(0.29)\end{array}$ & $\begin{array}{l}3.84 \\
(0.28)\end{array}$ & $\begin{array}{l}84.7 \\
(4.8)\end{array}$ & $\begin{array}{l}9.15 \\
(0.27)\end{array}$ & $\begin{array}{l}33.20 \\
(1.97)\end{array}$ & $\begin{array}{l}2.67 \\
(0.23)\end{array}$ \\
\hline$(\%)$ & 100 & 100 & 0.88 & 1.59 & 2.47 & 1.11 & 5.89 & 0.44 & 1.72 \\
\hline 2 & $\begin{array}{l}157.7 \\
(5.3)\end{array}$ & $\begin{array}{l}7478 \\
(127)\end{array}$ & $\begin{array}{l}1.46 \\
(0.13)\end{array}$ & $\begin{array}{l}2.69 \\
(0.22)\end{array}$ & $\begin{array}{l}4.15 \\
(0.11)\end{array}$ & $\begin{array}{l}68.3 \\
(4.2)\end{array}$ & $\begin{array}{l}7.71 \\
(0.13)\end{array}$ & $\begin{array}{l}45.35 \\
(2.27)\end{array}$ & $\begin{array}{l}4.92 \\
(0.26)\end{array}$ \\
\hline$(\%)$ & 100 & 100 & 0.92 & 1.71 & 2.63 & 0.91 & 4.89 & 0.61 & 3.12 \\
\hline 3 & $\begin{array}{l}150.0 \\
(5.2)\end{array}$ & $\begin{array}{l}7309 \\
(122)\end{array}$ & $\begin{array}{l}0.31 \\
(0.03)\end{array}$ & $\begin{array}{l}2.29 \\
(0.17)\end{array}$ & $\begin{array}{l}2.60 \\
(0.16)\end{array}$ & $\begin{array}{l}58.1 \\
(4.3)\end{array}$ & $\begin{array}{l}3.59 \\
(0.20)\end{array}$ & $\begin{array}{l}45.09 \\
(2.25)\end{array}$ & $\begin{array}{l}4.89 \\
(0.25)\end{array}$ \\
\hline$(\%)$ & 100 & 100 & 0.21 & 1.53 & 1.73 & 0.80 & 2.40 & 0.62 & 3.26 \\
\hline 4 & $\begin{array}{l}151.3 \\
(5.2)\end{array}$ & $\begin{array}{l}7321 \\
(119)\end{array}$ & $\begin{array}{l}0.15 \\
(0.02)\end{array}$ & $\begin{array}{l}1.71 \\
(0.07)\end{array}$ & $\begin{array}{l}1.86 \\
(0.08)\end{array}$ & $\begin{array}{l}58.9 \\
(4.1)\end{array}$ & $\begin{array}{l}3.21 \\
(0.14)\end{array}$ & $\begin{array}{l}41.52 \\
(2.29)\end{array}$ & $\begin{array}{l}5.24 \\
(0.30)\end{array}$ \\
\hline$(\%)$ & 100 & 100 & 0.10 & 1.13 & 1.23 & 0.80 & 2.12 & 0.57 & 3.47 \\
\hline 5 & $\begin{array}{l}150.4 \\
(5.5)\end{array}$ & $\begin{array}{l}7204 \\
(146)\end{array}$ & $\begin{array}{l}0.40 \\
(0.03)\end{array}$ & $\begin{array}{l}0.91 \\
(0.05)\end{array}$ & $\begin{array}{l}1.30 \\
(0.05)\end{array}$ & $\begin{array}{l}56 . \\
(4.9)\end{array}$ & $\begin{array}{l}3.15 \\
(0.22)\end{array}$ & $\begin{array}{l}42.98 \\
(0.58)\end{array}$ & $\begin{array}{l}4.70 \\
(0.17)\end{array}$ \\
\hline$(\%)$ & 100 & 100 & 0.27 & 0.60 & 0.86 & 0.78 & 2.09 & 0.60 & 3.13 \\
\hline 6 & $\begin{array}{l}150.2 \\
(5.7)\end{array}$ & $\begin{array}{l}7175 \\
(148)\end{array}$ & $\begin{array}{l}0.38 \\
(0.03)\end{array}$ & $\begin{array}{l}1.02 \\
(0.11)\end{array}$ & $\begin{array}{l}1.40 \\
(0.10)\end{array}$ & $\begin{array}{l}54.4 \\
(4.1)\end{array}$ & $\begin{array}{l}3.01 \\
(0.17)\end{array}$ & $\begin{array}{l}53.03 \\
(1.43)\end{array}$ & $\begin{array}{l}5.30 \\
(0.17)\end{array}$ \\
\hline$(\%)$ & 100 & 100 & 0.25 & 0.68 & 0.93 & 0.76 & 2.01 & 0.74 & 3.53 \\
\hline 7 & $\begin{array}{l}150.6 \\
(5.4)\end{array}$ & $\begin{array}{l}7128 \\
(158)\end{array}$ & $\begin{array}{l}0.39 \\
(0.03)\end{array}$ & $\begin{array}{l}1.55 \\
(0.15)\end{array}$ & $\begin{array}{l}1.95 \\
(0.15)\end{array}$ & $\begin{array}{l}59.8 \\
(5.3)\end{array}$ & $\begin{array}{l}3.80 \\
(0.27)\end{array}$ & $\begin{array}{l}46.30 \\
(0.63)\end{array}$ & $\begin{array}{l}4.41 \\
(0.10)\end{array}$ \\
\hline$(\%)$ & 100 & 100 & 0.26 & 1.03 & 1.29 & 0.84 & 2.53 & 0.65 & 2.93 \\
\hline 8 & $\begin{array}{l}148.9 \\
(5.3)\end{array}$ & $\begin{array}{l}6946 \\
(134)\end{array}$ & $\begin{array}{l}0.21 \\
(0.04)\end{array}$ & $\begin{array}{l}0.72 \\
(0.07)\end{array}$ & $\begin{array}{l}0.93 \\
(0.11)\end{array}$ & $\begin{array}{l}51.9 \\
(5.2)\end{array}$ & $\begin{array}{l}2.99 \\
(0.22)\end{array}$ & $\begin{array}{l}33.95 \\
(2.14)\end{array}$ & $\begin{array}{l}5.04 \\
(0.24)\end{array}$ \\
\hline$(\%)$ & 100 & 100 & 0.14 & 0.48 & 0.62 & 0.75 & 2.01 & 0.49 & 3.38 \\
\hline
\end{tabular}

Values represent means of all sites with $+/-\mathrm{SE}$ in parentheses, units are $\mathrm{mg}$ per microcosm. For week zero a litter amount of $15 \mathrm{~g}$ dw was estimated, since the samples were taken out of the original litter pool. The percentage is given for each week while elemental $\mathrm{C}$ and $\mathrm{N}$ analyses were regarded as $100 \%$

TIN total inorganic nitrogen, TOC total organic carbon, TDN total dissolved nitrogen, $C_{\text {mic }}$ microbial biomass $\mathrm{C}, N_{\text {mic }}$ microbial biomass $\mathrm{N}(n=4)$

(KL). Linear regressions were calculated for C-loss from $\mathrm{CO}_{2}$-respiration and $\mathrm{C}$-loss from the gravimetric mass-loss determination over all time points, with coefficients of determination $\left(\mathrm{r}^{2}\right)$ ranging from 0.68 (AK) to $0.92(\mathrm{KL})$. The final C-loss was on average 1.6-fold higher from the gravimetric (together with the elemental analysis) determination method than from the respiration.

NPOC, TDN, $\mathrm{C}_{\text {mic }}$ and $\mathrm{N}_{\text {mic }}$ content

Non purgeable organic $\mathrm{C}$ and total dissolved $\mathrm{N}$ (NPOC and TDN, Table 2, Fig. 2a and b) decreased over time, with significant differences between litters from different sites at week four and eight. A strong positive relation between NPOC and TDN was observed by single linear regression analysis $(p<0.001$, $\left.\mathrm{r}^{2}=0.78\right)$. The time course of NPOC was similar to that of TDN, except that TDN was highest for KL and lowest for $\mathrm{AK}$ most of the time. The $\mathrm{C}: \mathrm{N}$ ratio of non purgeable organic $\mathrm{C}$ and total dissolved $\mathrm{N}$ (NPOC:TDN) increased between start and end of the experiment for all sites, and its time course is shown in Fig. 2c.

Linear regression analysis for each separate site revealed a strong positive correlation between DON (= TDN - inorganic N) and $\mathrm{NH}_{4}{ }^{+}$(with $\mathrm{r}^{2}$-values ranging from $0.60(\mathrm{KL})$ to $0.97(\mathrm{AK})$ ) as well as a 
Fig. 2 Time course of a) non-purgeable organic carbon $(N P O C)$ b) total dissolved nitrogen $(T D N), \mathbf{c})$ ratio of NPOC and TDN (NPOC:TDN). The remaining graph d) represents a quadratic regression between TDN and the cumulative litter mass loss $(M L)$. The values for TDN between $\mathbf{b}$ ) and d) differ, since the first week was not used for mass loss determination. The outer lines of the regression curves indicate a $95 \%$ confidence interval and the line in between is the regression line. An ANOVA was conducted for week 4 and 8 to detect significant differences between the four sites. (ns $p>0.5 ; * p<$ $0.05 ; * * p<0.01 ; * * * p<$ 0.001). $A K$ Achenkirch, $K L$ Klausen-Leopoldsdorf, $O R$ Ort, PE Perg
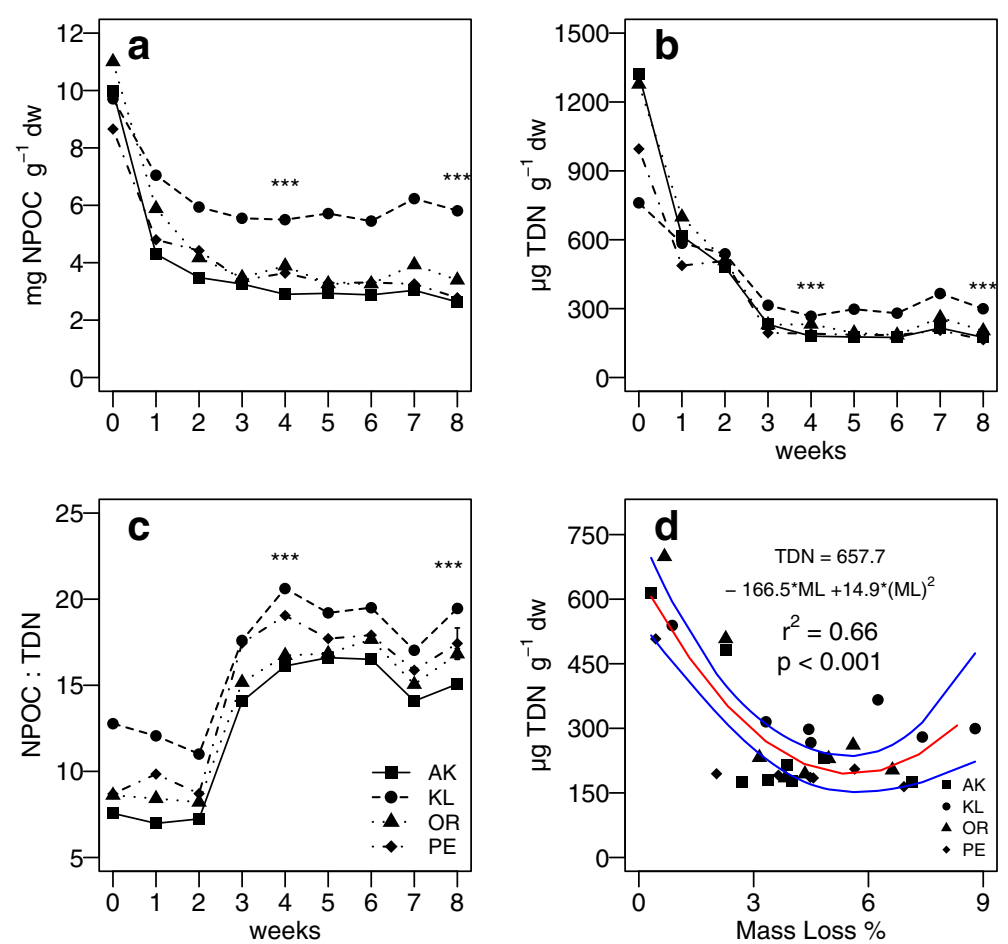

quadratic regression revealed a strong correlation between TDN and mass loss calculated with mean values over all sites (Fig. 2d, $n=30$, without week zero and two slightly negative values after week $1, p<0.001, \mathrm{r}^{2}=$ $0.66)$. Also for NPOC:TDN and litter mass loss $(p<$ $\left.0.001, \mathrm{r}^{2}=0.57\right)$ a quadratic regression was calculated.

For $\mathrm{C}_{\text {mic }}$ and $\mathrm{N}_{\text {mic }}$ (Table 2, Fig. 3a and b) a similar trend over time was observed and they were well correlated (Spearman's $\mathrm{r}=0.66, p<0.001$ ). Initially $\mathrm{N}_{\text {mic }}$ was low but sharply increased in the first 3 weeks. For the time period of the whole experiment $\mathrm{C}_{\text {mic }}$ and $\mathrm{N}_{\text {mic }}$ mostly was highest in KL. The C:N-ratio in microbial biomass $\left(\mathrm{C}_{\text {mic }}: \mathrm{N}_{\text {mic }}\right)$ declined over time starting from 18.1 in week 0 to 6.7 in week 8 for all sites. The course of $\mathrm{N}_{\text {mic }}$ inversely matched the development of $\mathrm{NH}_{4}{ }^{+}$and a highly significant quadratic relationship was observed between those two variables (Fig. 3c). This suggests that most of the $\mathrm{NH}_{4}{ }^{+}$was incorporated into microbial biomass within the first week.

For receiving a short outline, we provided a table with the examined nutrient pools during the time course of the experiment (Table 2). The proportions of NPOC (below $2 \%$ ), TDN (below $11 \%$ ), $\mathrm{C}_{\text {mic }}$ (below $1 \%$ ) and $\mathrm{N}_{\text {mic }}$ (below $5 \%$ ) in comparison to the total $\mathrm{C}$ and $\mathrm{N}$ amount of the litter, averaged for litter across all sites, were small.
Microbial metabolic quotient

The microbial metabolic quotient $\left(\mathrm{qCO}_{2}\right)$ was calculated as respiration divided by $\mathrm{C}_{\text {mic }}$ (Fig. $3 \mathrm{~d}$ ). A decrease during the time course of the experiment was observed with values ranging from $45.34 \mathrm{mg} \mathrm{CO}-\mathrm{C}$ $\mathrm{g}^{-1} \mathrm{C}_{\text {mic }} \mathrm{h}^{-1}$ (KL) at week zero to $1.98(\mathrm{AK})$ at week eight. Since respiration was measured in four separated microcosms, an ANOVA only was conducted for week eight. A strong positive relationship for the duration of the experiment over all sites was noticed between $\mathrm{qCO}_{2}$ and log-transformed TIN $\left(p<0.001, \mathrm{r}^{2}=0.70\right)$.

\section{Multivariate relationships}

A PCA was computed with $\mathrm{NO}_{3}{ }^{-}, \mathrm{NH}_{4}{ }^{+}$, respiration, NPOC, TDN, $\mathrm{C}_{\text {mic }}$ and $\mathrm{N}_{\text {mic }}$ (Fig. 4a). The arithmetic mean was calculated for each harvest time point and litter site, resulting in 36 observations and seven variables. The analysis revealed two principal components (PC). The first one was mainly explained by TDN $(+0.94), \mathrm{N}_{\text {mic }}(-0.80), \mathrm{NH}_{4}^{+}(+0.75)$ and $\mathrm{C}_{\text {mic }}$ $(-0.51)$ and it explained $59.6 \%$ of the variation and the second one by $\mathrm{NO}_{3}^{-}(+0.71)$, respiration $(+0.56)$ and $\mathrm{C}_{\text {mic }}(+0.26)$ and it explained $23.8 \%$ of the 

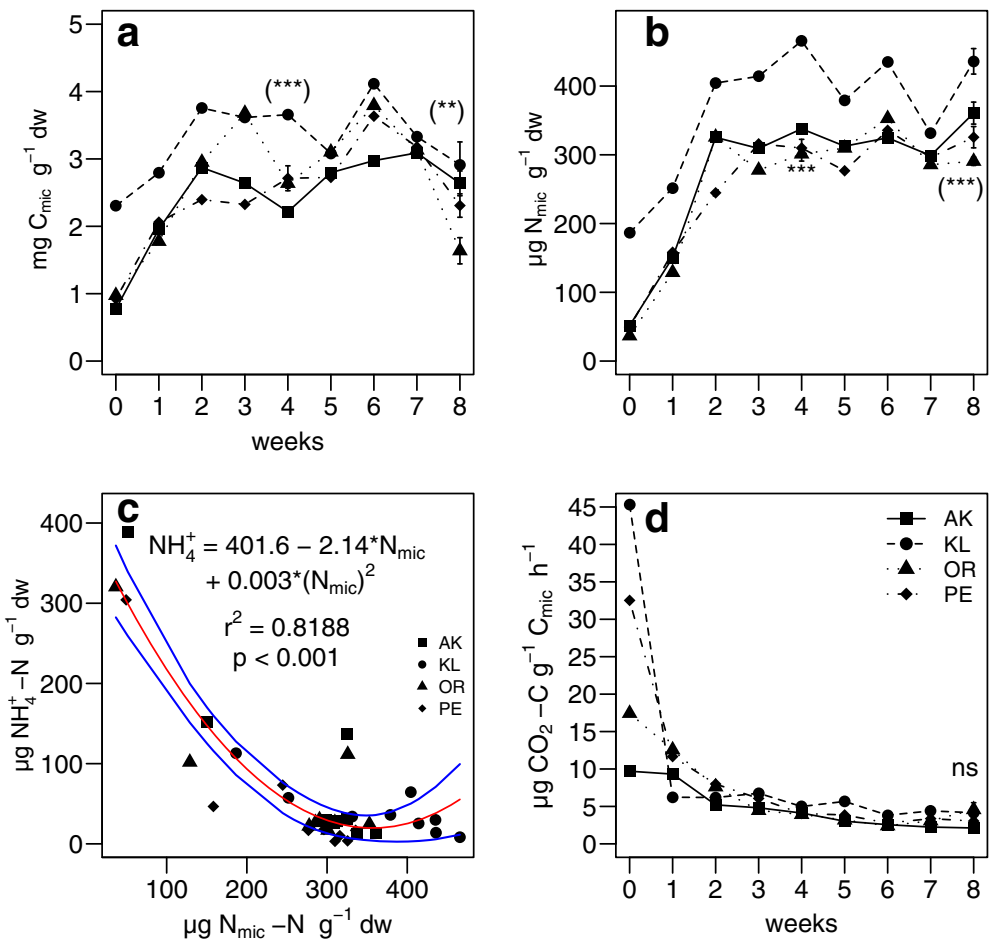

Fig. 3 Time course of a) microbial biomass $\mathrm{C}\left(C_{\text {mic }}\right)$, b) microbial biomass $\mathrm{N}\left(N_{\text {mic }}\right)$ and $\left.\mathbf{d}\right)$ the microbial metabolic quotient $\left(q \mathrm{CO}_{2}\right)$. The remaining graph c) represents a quadratic regression between $\mathrm{NH}_{4}{ }^{+}$and microbial biomass $\mathrm{N}\left(N_{\text {mic }}\right)$. The outer lines of the regression curves indicate a $95 \%$ confidence interval and the line in between is the regression line. In a) and b) an ANOVA was conducted for week four and eight to detect

significant differences between the four sites, and in d) for week eight only. Where brackets indicate a violation of the prerequisite of homogenous variances, a non-parametric Kruskal-Wallis test was computed (ns $p>0.5 ; * p<0.05 ; * * p<0.01$; *** $p<$ 0.001). $A K$ Achenkirch, $K L$ Klausen-Leopoldsdorf, $O R$ Ort, $P E$ Perg

variation. Figure $4 \mathrm{a}$ shows that "time" was a more separating factor than "site", indicating the stronger influence in comparison. Respiration and consequently litter mass loss was also influenced by TIN, as a strong negative correlation between TIN and Litter mass loss was detected $\left(p<0.001\right.$ and $\left.\mathrm{r}^{2}=0.60\right)$. As expected, TIN was correlated with NPOC:TDN $(p<$ $\left.0.001, \mathrm{r}^{2}=0.56\right)$ and furthermore with TDN $(p<0.001$, $\left.\mathrm{r}^{2}=0.71\right)$, since the TIN provides a portion of the TDN ranging from $19 \%$ (KL, week 8$)-92 \%$ (PE, week 3 ) over the whole experiment. Litter from KL showed the highest respiration and lowest $\mathrm{NH}_{4}{ }^{+}$-concentration.

\section{Phospholipid fatty acids}

PLFA data were classified into actinomycetes, fungi, gram + and gram- bacteria, and protozoa. Initially gram- bacteria dominated all microbial communities and only fungi and actinomycetes were significantly different among litters from different sites (Table 3).

The total amount of PLFAs did not change significantly with time. In week zero $54.3 \mathrm{nmol} \mathrm{g}^{-1} \mathrm{dw} \pm 0.7$ (SE, $n=12$ ), in week four $56.1 \pm 0.6 \mathrm{nmol} \mathrm{g}^{-1} \mathrm{dw}$ (SE, $n=16)$ and in week eight $53.3 \pm 1.4 \mathrm{nmol} \mathrm{g}^{-1} \mathrm{dw}$ (SE, $n=20)$ total PLFAs were measured.

However, the relative abundance among certain microbial groups did change with time, as revealed by one-way ANOVA. During the first 4 weeks of the experiment all groups except gram- bacteria increased. This was followed by a general decrease of all groups, with exception of actinomycetes and gram + bacteria, which both increased in microcosms of OR. For litter from all sites fungi increased in the first 4 weeks. From weeks four to eight, however, differences in the relative abundance of different microbial groups differed among litters. For example: litter of two sites gained in fungal biomass (AK, KL) while other two declined (OR, PE). In general, however, fungi showed a significant increase throughout the course of the experiment (ANOVA, $p<0.001$ ). 


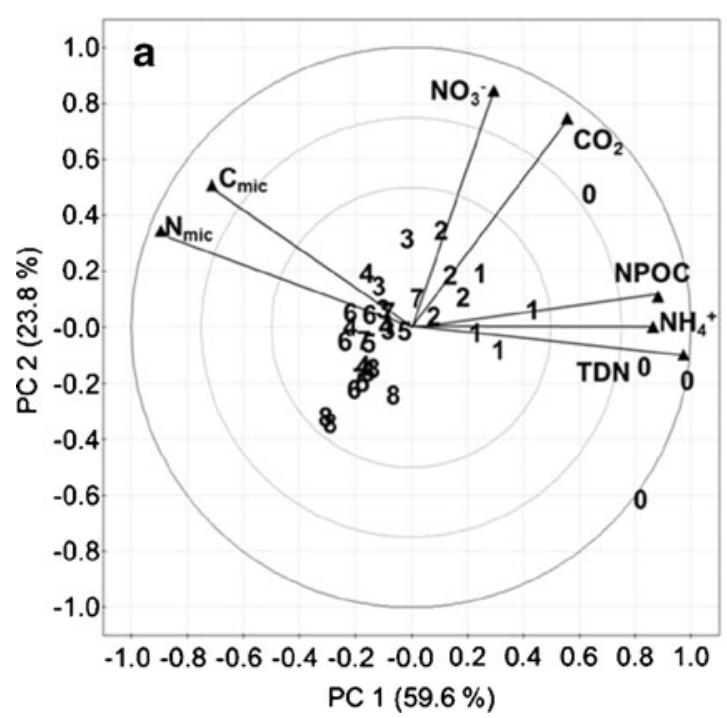

Fig. 4 Principal component analysis of a) inorganic N-pools, $\mathrm{CO}_{2}$-respiration, non purgeable organic $\mathrm{C}$, total dissolved $\mathrm{N}$, microbial biomass $\mathrm{C}$ and $\mathrm{N}$ and $\mathbf{b}$ ) the same variables including PLFA data. Data points (indicated as numbers in a) and points in b) represent litter samples from four sites at a) eight (week 0-8), respectively b) three (week $0,4,8$ ) time points. The variables $\mathrm{NH}_{4}{ }^{+}, \mathrm{NO}_{3}{ }^{-}, \mathrm{CO}_{2}$ and $\mathrm{N}_{\text {mic }}$ have been log-transformed prior to

In the microcosms of OR most gram + bacteria and actinomycetes were found. Gram- bacteria decreased

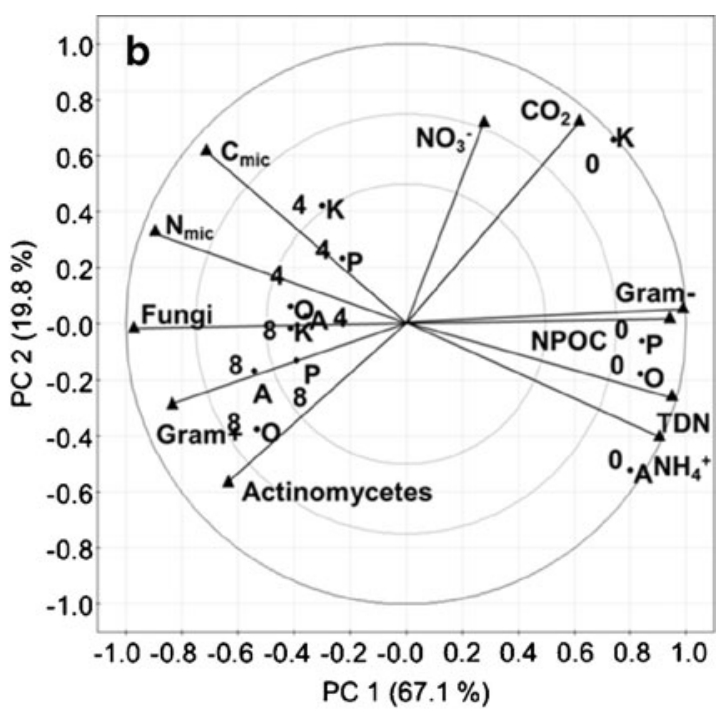

PCA calculation for a) and $\mathrm{NO}_{3}{ }^{-}$and $\mathrm{CO}_{2}$ for $\mathbf{b}$ ). Explanation of variance by means of individual principal components (PC) is shown through percentages. Numbers indicate time and letters sites. $C_{\text {mic }}$ microbial biomass $\mathrm{C}, N_{\text {mic }}$ microbial biomass N, TDC total dissolved $\mathrm{C}, T D N$ total dissolved N, A Achenkirch, $K$ Klausen-Leopoldsdorf, $O$ Ort, $P$ Perg

on average for all sites from $43.4 \mathrm{nmol} \mathrm{g}{ }^{-1} \mathrm{dw}$ at week zero to $30.3 \mathrm{nmol} \mathrm{g}^{-1} \mathrm{dw}$ in week eight, and fungi

Table 3 PLFA-contents of beech leaf litter of four sites at three time points

\begin{tabular}{|c|c|c|c|c|c|c|c|}
\hline Site & Actinomycetes & Fungi & Gram + & Gram - & Protozoa & FB-Ratio & Total PLFAs \\
\hline \multicolumn{8}{|c|}{ Week $0(n=3)$} \\
\hline $\mathrm{AK}$ & $0.20^{\mathbf{b}}(0.03)$ & $9.93(0.76)$ & $1.20^{\mathbf{a}}(0.09)$ & $42.41(2.70)$ & $0.264(0.022)$ & $0.22(0.03)$ & $54.01^{\mathbf{a b}}(1.81)$ \\
\hline KL & $0.01^{\mathrm{a}}(0.01)$ & $7.63(0.09)$ & $0.83^{\mathrm{a}}(0.01)$ & $42.39(0.10)$ & $0.213(0.014)$ & $0.17(<0.01)$ & $51.07^{\mathrm{a}}(0.08)$ \\
\hline OR & $0.29^{\mathbf{b}}(0.04)$ & $9.62(0.71)$ & $2.54^{\mathbf{b}}(0.23)$ & $43.54(1.75)$ & $0.318(0.042)$ & $0.20(0.02)$ & $56.31^{\mathbf{b}}(0.76)$ \\
\hline PE & $0.21^{\mathbf{b}}(0.03)$ & $8.71(0.16)$ & $1.30^{\mathbf{a}}(0.05)$ & $45.28(0.28)$ & $0.329(0.016)$ & $0.18(<0.01)$ & $55.83^{\mathbf{b}}(0.04)$ \\
\hline \multicolumn{8}{|c|}{ Week $4(n=4)$} \\
\hline $\mathrm{AK}$ & $0.32^{\mathrm{c}}(0.01)$ & $18.12^{\mathbf{a b}}(0.25)$ & $4.41^{\mathrm{c}}(0.13)$ & $30.60^{\mathrm{a}}(0.75)$ & $0.499^{\mathbf{b}}(0.018)$ & $0.48(0.01)$ & $53.95(0.85)$ \\
\hline KL & $0.24^{\mathbf{b}}(<0.01)$ & $18.27^{\mathbf{a b}}(0.17)$ & $3.85^{\mathbf{b}}(0.06)$ & $34.28^{\mathbf{b}}(0.95)$ & $0.427^{\mathbf{a}}(0.005)$ & $0.45(0.01)$ & $56.74(1.47)$ \\
\hline OR & $0.41^{\mathbf{d}}(<0.01)$ & $18.77^{\mathbf{b}}(0.17)$ & $7.11^{\mathbf{d}}(0.15)$ & $31.05^{\mathbf{a b}}(0.88)$ & $0.466^{\mathbf{a b}}(0.004)$ & $0.46(0.01)$ & $57.81(0.95)$ \\
\hline $\mathrm{PE}$ & $0.22^{\mathrm{a}}(<0.01)$ & $17.68^{\mathrm{a}}(0.27)$ & $3.36^{\mathbf{a}}(0.09)$ & $33.50^{\mathbf{a b}}(0.74)$ & $0.892^{\mathrm{c}}(0.023)$ & $0.45(0.01)$ & $55.65(1.00)$ \\
\hline \multicolumn{8}{|c|}{ Week $8(n=5)$} \\
\hline $\mathrm{AK}$ & $0.37^{\mathbf{a b}}(<0.01)$ & $18.88(0.08)$ & $5.35^{\mathrm{a}}(0.10)$ & $28.69^{\mathrm{a}}(0.46)$ & $0.474^{\mathrm{a}}(0.026)$ & $0.52(<0.01)$ & $52.93^{\mathrm{a}}(0.09)$ \\
\hline KL & $0.42^{\mathbf{b}}(0.03)$ & $18.33(1.49)$ & $4.79^{\mathbf{a}}(0.20)$ & $30.90^{\mathbf{b c}}(0.59)$ & $0.491^{\mathrm{a}}(0.015)$ & $0.48(0.05)$ & $54.92^{\mathbf{a b}}(0.75)$ \\
\hline OR & $0.71^{\mathbf{c}}(0.02)$ & 17.05 (1.09) & $9.14^{\mathbf{b}}(0.37)$ & $29.68^{\mathbf{a b}}(0.37)$ & $0.489^{\mathrm{a}}(0.013)$ & $0.45(0.04)$ & $57.39^{\mathbf{b}}(0.60)$ \\
\hline $\mathrm{PE}$ & $0.31^{\mathrm{a}}(0.01)$ & $16.72(1.16)$ & $5.28^{\mathrm{a}}(0.30)$ & $31.79^{\mathbf{c}}(0.56)$ & $0.858^{\mathbf{b}}(0.055)$ & $0.42(0.04)$ & $54.96^{\mathbf{a b}}(0.58)$ \\
\hline
\end{tabular}

Accounting PLFAs have been summed up to result in the assigned groups. Values represent means with $+/-$ SE in parentheses, different letters indicate significant differences between sites for each time point after Tukey's HSD test $(p=0.05)$. Except for FB-Ratio all units are $n M o l$ PLFA g ${ }^{-1} \mathrm{dw}$

FB-Ratio fungal bacterial ratio, $A K$ Achenkirch, $K L$ Klausen-Leopoldsdorf, $O R$ Ort, $P E$ Perg 
increased from 9.0 to $17.6 \mathrm{nmol} \mathrm{g}^{-1} \mathrm{dw}$. Significant correlations were observed for gram + bacteria and actinomycetes (Pearson's $\mathrm{r}=0.91, p<0.001$ ), gram + with gram- bacteria (Spearman's $r=-0.83, p=0.001$ ) and fungi and gram- bacteria (Spearman's $r=-0.75$, $p<0.01)$. A PCA was conducted, containing all the PLFA groups and respiration, $\mathrm{NH}_{4}{ }^{+}, \mathrm{NO}_{3}{ }^{-}, \mathrm{TDN}$, NPOC, $\mathrm{N}_{\text {mic }}$ and $\mathrm{C}_{\text {mic }}$ (Fig. $4 \mathrm{~b}$ ). Prior to performing the PCA, the arithmetic mean of the data set was calculated for three harvests (at week zero, four and eight) and each site, resulting in 12 observations and 11 variables. Three PCs were calculated. The first PC was mostly explained by gram- bacteria $(+0.97)$, fungi $(-0.94)$, TDN $(+0.90)$, NPOC $(+0.89), \mathrm{NH}_{4}{ }^{+}(+0.82)$, $\mathrm{N}_{\text {mic }}(-0.80)$, gram + bacteria $(-0.69)$ and $\mathrm{C}_{\text {mic }}$ $(-0.51)$, the second one by $\mathrm{CO}_{2}(+0.53), \mathrm{NO}_{3}{ }^{-}$ $(+0.52)$ and actinomycetes $(-0.31)$. The third PC explained less than $1 \%$ of total variation. Microbial community composition changed rapidly within the first 4 weeks, whereas only minor shifts occurred from week four to eight. The PCA also showed, that week zero was more different than week four and eight, which grouped closer together (Fig. 4b).

The results of the PCA revealed certain interrelationships between microbial community data and litter chemistry. Actinomycetes and fungi were negatively correlated with respiration. Gram- bacteria were positively and fungi negatively correlated with TDN and $\mathrm{NH}_{4}$. The concentration of $\mathrm{NH}_{4}^{+}$was highest in the first week and decreased over time as did gram- bacteria. Factors on the $\mathrm{qCO}_{2}$ cannot be easily derived from the picture. There was a strong negative correlation between fungal-bacteria ratio (FB-ratio) and $\mathrm{C}_{\text {mic }}$ : $\mathrm{N}_{\text {mic }}$ (Spearman's $r=-0.62, p<0.05$ ) as well as with TIN (Spearman's $r=-0.59, p<0.05$ ). The qCO2 was strongly negatively correlated with fungi (Spearman's $r=-0.75, p<0.01)$ and positively with gram- bacteria (Spearman's $r=0.85, p<0.001$ ).

\section{Discussion}

The influence of $\mathrm{N}$ on early beech litter decomposition (i)

During the early stages of decomposition, microbial N limitation can occur due to high microbial $\mathrm{N}$ demand (Moorhead and Sinsabaugh 2006). Thus, N is proposed to accelerate decomposition during the early stages. We were not able to explain differences in respiration rates among leaf litter from the four sites neither by initial bulk N-content nor by bulk C:Nratios as suggested by Zhang et al. (2008), which would negate our first research question (i) "Would higher initial $\mathrm{N}$ content and lower $\mathrm{C}: \mathrm{N}$ ratios accelerate early stage decomposition rates?". This might be attributed to the fact, that the present experiment is using only litter from four sites for evaluating this impact. We therefore tried to evaluate different influencing factors on respiration.

A strong correlation of respiration and $\mathrm{C}: \mathrm{N}$ ratio of soluble $\mathrm{C}$ and $\mathrm{N}$ was observed in previous decomposition studies dealing with tropical tree species (Bernhard-Reversat 1999), and also for a decomposition study from temperate climate (Marstorp 1996). In addition, it has been mentioned, that mainly soluble carbon compounds (e.g. unshielded cellulose and hemicelluloses) are decomposed in early stages of decomposition (Berg and McClaugherty 2008). Since beech litter is considered to be rich in lignin (Melillo et al. 1982), a larger portion of cellulose may be shielded, increasing the influence of the soluble fractions during decomposition. We found that respiration was highest in leaf litter of sites with a high NPOC: TDN ratio, which is consistent with the idea, that this soluble $\mathrm{C}: \mathrm{N}$ is a good an indicator for the degradability of litter organic compounds (Bernhard-Reversat 1999). The influence of soluble compounds on litter decomposition has often been underestimated compared to litter chemistry stoichiometry (Cleveland et al. 2004). Moreover, an amount of about $10-40 \%$ of DOC (comparable with our NPOC) is quickly degraded within a period of days to a few months (Silveira et al. 2011). Our results emphasize the relationship between soluble compounds and respiration although the relationship between litter mass loss and TDN was even stronger.

Higher microbial $\mathrm{N}$ demand (Moorhead and Sinsabaugh 2006) at early stages was on the one hand supported by our study by the quick incorporation of $\mathrm{NH}_{4}{ }^{+}$, on the other hand a limitation of total $\mathrm{N}$ was not observed. The strong influence of soluble $\mathrm{C}$ and $\mathrm{N}$ together on this early stage decomposition could possibly explain this discrepancy: the bulk $\mathrm{C}: \mathrm{N}$ ratio in our beech litter was about fourfold higher than the more influencing NPOC:TDN. In comparison to the $\mathrm{C}_{\text {mic }}: \mathrm{N}_{\text {mic }}$ the NPOC:TDN was quite low in the beginning (0.6) and increased to 2.6 after 8 weeks for all sites. The bulk C:N stayed at a comparably similar 
level between start and ending of our experiment. This comparison supports the observation, that the bulk N of our litter was not limiting decomposition after 8 weeks (i). There was no correlation found between the bulk C:N and NPOC:TDC. The linear correlation of TDN with mass loss was strongly affected by the factor time, and sites neither highest in TDN nor in NPOC showed highest respiration in the beginning, where respiration was highest, whereas this was the case for the NPOC:TDN ratio.

Since the litter from the site KL showed the highest respiration and lowest $\mathrm{NH}_{4}{ }^{+}$-concentration, previous immobilization of $\mathrm{NH}_{4}^{+}$may have led to a negative relationship between $\mathrm{NH}_{4}{ }^{+}$-concentration and respiration. On the contrary we observed that sites with a higher proportion of $\mathrm{NH}_{4}{ }^{+}$in the TIN-pool resulted in lower respiration rates.

These findings are supported by quick incorporation of $\mathrm{NH}_{4}^{+}$that supposedly resulted in a transformation from inorganic $\mathrm{N}$ to organic amino compounds like glutamate or glutamine (Tempest and Meers 1973). This further indicates that although inorganic N, mainly as $\mathrm{NH}_{4}{ }^{+}$, might have been utilized by microbes and accumulated into microbial biomass, higher amounts of $\mathrm{NH}_{4}{ }^{+}$did not accelerate microbial respiration. This effect had been mentioned earlier as "ammonia metabolite repression" of fungi (Keyser et al. 1978). In the previous study $\mathrm{NH}_{4}{ }^{+}$was reported to be able to repress the synthesis of some fungal enzymes. If this mechanism for repressing expression of enzymes can also occur in a bacterial dominated microbial community our observation would indicate that the inhibition of fungal derived enzymes would slow down litter decomposition rates already at an early stage, as they are considered to be the main degraders of recalcitrant compounds in leaf litter (Keyser et al. 1978).

On average the gravimetric C-loss was 1.6-fold higher than $\mathrm{C}$-loss via $\mathrm{CO}_{2}$ after 8 weeks (the average $\mathrm{r}^{2}$ for each site was 0.83 ). We expected a similar Closs between both methods for calculating C-loss. A possible reason for the observed differences could be that mass loss was obtained from all microcosms after destructive sampling, calculated on a dry weight basis, whereas C-loss from respiration was measured in four particular microcosms only. Regardless the gravimetric and respiration C-loss were related with a 1.6-fold factor, this is a clear indication, that respiration and mass loss are closely coupled together and respiration is an appropriate measure for decomposition rate.
The influence of initial elemental content (ii)

Other nutrients beside $\mathrm{N}$ could have had an effect on decomposition rates. For example $\mathrm{Mn}$ as a component of the exoenzyme manganese peroxidase (Berg et al. 2007) could have been an important driver for decomposition, as litter from the most active site $\mathrm{K}$ also showed the highest $\mathrm{Mn}$ content. Also P, which is known to be able to influence decompostion rates (Hobbie and Vitousek 2000) as well as Calcium (Ca), since Ca stabilizes plant cell walls (Demarty et al. 1984) and therefore possibly reduces accessibility to nutrients for microbial decomposers.

While for Austrian beech litter a critical value of 1800 for the C:P ratio was proposed, above which $\mathrm{P}$ mineralization is inhibited (Mooshammer et al. 2011), the highest measured C:P ratio in this study was only 1708 for AK. Therefore it is assumed, that $\mathrm{P}$ was not limiting litter decomposition in this experiment, although litter from AK had lowest $\mathrm{P}$ concentration as well as respiration rates. This indicates, that the $\mathrm{P}$ concentration still might have influenced microbial activity - but as AK and OR showed highest concentrations of $\mathrm{Ca}$ and lowest respiration, a negative influence of $\mathrm{Ca}$ on decomposition also cannot be excluded. Potassium was significantly highest in concentration at the most active site KL. In addition it has been shown previously that the K-content stimulated litter decomposition rates of living plants of several British herbaceous species (Cornelissen and Thompson 2008). However, litter from four sites varying in several elemental concentrations might be too less to get clear predictions of a single element on litter decomposition rates.

\section{Microbial community changes (iii)}

Gram- bacteria initially dominated the microbial community followed by gram + bacteria and fungi, although gram- bacteria continued to have the highest relative abundance until the end of the experiment. These results matched our expectations, as bacteria are in general able to degrade easily accessible compounds available during the initial stages of decomposition. Bacteria in general are followed by an increase in fungal abundance after depletion of the easily accessible compounds as fungi are more specialized on the more recalcitrant fraction for degradation (Bossuyt et al. 2001; McMahon et al. 2005; Six et al. 2006). 
Similar shifts in microbial community composition were recorded for soils under an alpine grass and during primary succession (Tscherko et al. 2004), where initially dominating gram- bacteria were later succeeded by gram + bacteria and fungi. However, the data from this experiment were exclusively derived from decomposing leaf litter excluding soil. In addition the time course of this experiment was much shorter than most other decomposition studies and we assume that the substrates available in the early stages of decomposition will differ widely from most other decomposition experiments and also from litter studies including soil.

Whereas chloroform fumigation data indicated a steady increase in microbial biomass, there was no increase in total PLFA amount over the whole experiment. While in studies from other terrestrial decomposition experiments (Bailey et al. 2002; Leckie et al. 2004) a correlation between PLFA data and microbial biomass by chloroform fumigation was found, this was not observed in the present study. Bacteria are believed to contain more PLFAs per $\mathrm{g}$ biomass compared to fungi (Joergensen and Wichern 2008) and the observed decrease of gram- bacteria and increase of fungi over time could be another reason for not finding a correlation between total PLFA and $\mathrm{C}_{\text {mic }}$.

It would have been expected, that with increasing fungal biomass, the microbial $\mathrm{C}: \mathrm{N}$ ratio would increase as well (Campbell et al. 1991). In the present study, the $\mathrm{C}_{\text {mic }}: \mathrm{N}_{\text {mic }}$ decreased, averaged for all sites, over time from 19.0 in week zero to 6.6 in week eight. The relatively high ratio in week zero could possibly be addressed to dormant bacteria or fungal spores, since soil microorganisms appear to be largely dormant (P. Lavelle et al. 1995). The reason for the lower ratio in the last week may be due to a decrease of $\mathrm{C}_{\text {mic }}$. Except for these 2 weeks the ratio seemed to be quite stable during the overall experiment (the average for all sites from week two to week eight was 9.9), which would be in accordance to the demand of microbial homeostasis (Cleveland and Liptzin 2007). Even though it has been mentioned that indicators for fungal biomass were correlated with $\mathrm{C}_{\mathrm{mic}}: \mathrm{N}_{\mathrm{mic}}$ ratio (Joergensen and Emmerling 2006), this was not always the case (e.g. Salamanca et al. 2002).

As microbial biomass was not related to respiration and litter mass loss in our experiment, the metabolic quotient (a combined factor) might provide a better insight. In the early stages respiration was highest, but microbial biomass was lowest indicating a decrease of $\mathrm{qCO}_{2}$ over all sites during the time course of the experiment. This is consistent with the decrease of the gram- bacteria and the increase of fungi, which are supposed to have a lower $\mathrm{qCO}_{2}$ (Grayston et al. 2001). Moreover, the coherency of $\mathrm{qCO}_{2}$, TIN and FB-ratio also indicated an impact of easily available $\mathrm{N}$, primarily of $\mathrm{NH}_{4}^{+}$, on $\mathrm{qCO}_{2}$. Higher values of $\mathrm{qCO}_{2}$ in earlier stages of this experiment with a higher gram- bacteria content indicated lower C-use efficiency. During later stages with increased dominance of fungi, the C-use efficiency would be expected to increase (Keiblinger et al. 2010), and therefore $\mathrm{qCO}_{2}$ to decrease. Litter quality was already defined as a decreasing function of time elsewhere (e.g. d'Annunzio et al. 2008), and in our early stage experiment many observed effects between the sites were superposed by the occurring time course. A previous study also observed that the combined "time-site" factor had a highly significant effect on extracellular enzyme activities (Keiblinger et al. 2012), which are of major importance in the breakdown of recalcitrant plant material. The response time of the microbial community was remarkably short: The microbial community structure significantly changed between week zero and week four. The differences between week four and week eight were only in a minor range in comparison indicating an early adaptation from week zero to week four. The already noticeable succession towards fungi after 4 weeks confirmed a strong impact of the more labile C- and N-pools on the microbial community as well as on the process of litter decomposition, since those pools also underwent the most pronounced changes in the very first weeks of the experiment in accordance with the stronger microbial respiration at the beginning.

\section{Conclusions}

During early stages of litter decomposition, the influence of NPOC:TDN on litter decomposition had a stronger effect on decomposition rates than bulk elemental stoichiometry. While it was expected that beech litter enriched in total $\mathrm{N}$ would show highest decomposition rates, in the present experiment this was not the case. Furthermore, sites lower in initial $\mathrm{NH}_{4}{ }^{+}-\mathrm{N}$ showed less respiration and mass loss. Initial beech litter elemental contents could have a possible 
influence on decomposition since $\mathrm{Mn}$ and $\mathrm{K}$, were highest in litter from the most active site (KL) and lowest in litter from the least active site (AK).

This experiment was unique in terms of temporal resolution in early stages of litter decomposition combined with a broad range of measurements of ecophysiological parameters. Over this short period of incubation (8 weeks), our data suggest that the factor "time" was more predictive than the factor "site", indicating that major changes occurred during the initial stages of decomposition, as had been observed for the microbial community structure. The shift from a generally bacterial dominated regime to an increase of fungal PLFAs was related with a decrease of respiration and an increase in metabolic quotient.

Acknowledgments This research was performed within the National Research network MICDIF (S100) of the Austrian Science Fund FWF (Project numbers S10001, 2, 3, 4, 6, 7B17). Special thanks to Michael Pfeffer for assistance with PLFA analysis, to Helene Hochrieser for statistical assistance, to Barbara Kitzler with the gas-measurements and to Brigitte Schraufstädter and Veronika Bendl for laboratory assistance. We are highly grateful to Marianne Koranda for support with the $\mathrm{C}_{\text {mic }}$ and $\mathrm{N}_{\text {mic }}$ measurements and to Alfred Fürst for measurements of element concentrations. We also want to express our gratitude to Edward K. Hall for a final proofreading of the manuscript. The Austrian Academy of Sciences (ÖAW) granted Katharina Keiblinger with a DOC-fFORTE fellowship.

Open Access This article is distributed under the terms of the Creative Commons Attribution License which permits any use, distribution, and reproduction in any medium, provided the original author(s) and the source are credited.

\section{References}

Aber JD, Melillo JM (1991) Terrestrial ecosystems. Saunders College Publishing, Orlando

Aerts R, de Caluwe H (1997) Nutritional and plant-mediated controls on leaf litter decomposition of Carex species. Ecology 78:244-260

Ambus P, Zechmeister-Boltenstern S, Butterbach-Bahl K (2006) Sources of nitrous oxide emitted from European forest soils. Biogeosciences 3:135-145

Bailey VL, Peacock AD, Smith JL, Bolton H (2002) Relationships between soil microbial biomass determined by chloroform fumigation-extraction, substrate-induced respiration, and phospholipid fatty acid analysis. Soil Biol Biochem 34:1385-1389

Berg B (2000) Litter decomposition and organic matter turnover in northern forest soils. For Ecol Manage 133:13-22

Berg B and McClaugherty C (2008) Litter decomposition - a set of different processes. In: Plant litter decomposition, humus formation, carbon sequestration, 2nd edn. Springer, Berlin Heidelberg, pp 11-14

Berg B, Mcclaugherty C, Johansson MB (1993) Litter mass-loss rates in late stages of decomposition at some climatically and nutritionally different pine sites - long-term decomposition in a scots pine forest.8. Canadian Journal of BotanyRevue Canadienne De Botanique 71:680-692

Berg B, Steffen KT, McClaugherty C (2007) Litter decomposition rate is dependent on litter Mn concentrations. Biogeochemistry 82:29-39

Bernhard-Reversat F (1999) Changes in relationships between initial litter quality and $\mathrm{CO} 2$ release during early laboratory decomposition of tropical leaf litters. Eur J Soil Biol 34:117-122

Boer WD, Folman LB, Summerbell RC, Boddy L (2006) Living in a fungal world: impact of fungi on soil bacterial niche development. FEMS Microbiol Rev 29:795-811

Bossuyt H, Denef K, Six J, Frey S, Merckx R, Paustian K (2001) Influence of microbial populations and residue quality on aggregate stability. Appl Soil Ecol 16:195-208

Campbell CA, Biederbeck VO, Zentner RP, Lafond GP (1991) Effect of crop rotations and cultural practices on soil organic matter, microbial biomass and respiration in a thin black Chernozem. Can J Soil Sci 71:363-376

Chesson A, Cadisch G and Giller K (1997) Plant degradation by ruminants: parallels with litter decomposition in soils. Driven by nature: plant litter quality and decomposition. 47-66

Cleveland CC, Liptzin D (2007) C:N:P stoichiometry in soil: is there a "Redfield ratio" for the microbial biomass? Biogeochemistry 85:235-252

Cleveland CC, Neff JC, Townsend AR, Hood E (2004) Composition, dynamics, and fate of leached dissolved organic matter in terrestrial ecosystems: results from a decomposition experiment. Ecosystems 7:175-285

Cornelissen JHC, Thompson K (2008) Functional leaf attributes predict litter decomposition rate in herbaceous plants. New Phytol 135:109-114

Craine JM, Morrow C, Fierer N (2007) Microbial nitrogen limitation increases decomposition. Ecology 88:2105-2113

d'Annunzio R, Zeller B, Nicolas M, Dhôte JF, Saint-André L (2008) Decomposition of European beech (Fagus sylvatica) litter: combining quality theory and ${ }^{15} \mathrm{~N}$ labelling experiments. Soil Biol Biochem 40:322-333

Das M, Royer TV, Leff LG (2007) Diversity of fungi, bacteria, and actinomycetes on leaves decomposing in a stream. Appl Environ Microbiol 73:756-767

Demarty M, Morvan C, Thellier M (1984) Calcium and the cellwall. Plant Cell Environ 7:441-448

Elser JJ, Nagy JD, Kuang Y (2003) Biological stoichiometry: an ecological perspective on tumor dynamics. Bioscience 53:1112-1120

Fierer N, Schimel JP, Holden PA (2003) Variations in microbial community composition through two soil depth profiles. Soil Biol Biochem 35:167-176

Frostegard A, Baath E (1996) The use of phospholipid fatty acid analysis to estimate bacterial and fungal biomass in soil. Biol Fertil Soils 22:59-65

Frostegard A, Tunlid A, Baath E (1991) Microbial biomass measured as total lipid phosphate in soils of different organic content. J Microbiol Methods 14:151-163

Frostegard A, Tunlid A, Baath E (1993) Phospholipid fattyacid composition, biomass, and activity of microbial 
communities from 2 soil types experimentally exposed to different heavy-metals. Appl Environ Microbiol 59:3605-3617

Gallo M, Amonette R, Lauber C, Sinsabaugh RL, Zak DR (2004) Microbial community structure and oxidative enzyme activity in nitrogen-amended north temperate forest soils. Microb Ecol 48:218-229

Grayston SJ, Griffith GS, Mawdsley JL, Campbell CD, Bardgett RD (2001) Accounting for variability in soil microbial communities of temperate upland grassland ecosystems. Soil Biol Biochem 33:533-551

Güsewell S, Gessner MO (2009) N: P ratios influence litter decomposition and colonization by fungi and bacteria in microcosms. Funct Ecol 23:211-219

Hackl E, Pfeffer M, Donat C, Bachmann G, ZechmeisterBoltenstern S (2005) Composition of the microbial communities in the mineral soil under different types of natural forest. Soil Biol Biochem 37:661-671

Henriksen TM, Breland TA (1999) Nitrogen availability effects on carbon mineralization, fungal and bacterial growth, and enzyme activities during decomposition of wheat straw in soil. Soil Biol Biochem 31:1121-1134

Henschler G (1988) Analysen im biologischen material Vol. 2. $\mathrm{VCH}$ Verlagsgesellschaft $\mathrm{mbH}$, Weinheim

Hieber M, Gessner MO (2002) Contribution of stream detrivores, fungi, and bacteria to leaf breakdown based on biomass estimates. Ecology 83:1026-1038

Hobbie SE, Vitousek PM (2000) Nutrient limitation of decomposition in Hawaiian forests. Ecology 81:1867-1877

Hofrichter M (2002) Review: lignin conversion by manganese peroxidase (MnP). Enzyme Microb Technol 30:454-466

Jacob M, Viedenz K, Polle A, Thomas FM (2010) Leaf litter decomposition in temperate deciduous forest stands with a decreasing fraction of beech (Fagus sylvatica). Oecologia 164:1083-1094

Joergensen RG, Emmerling C (2006) Methods for evaluating human impact on soil microorganisms based on their activity, biomass and diversity in agricultural soils. J Plant Nutr Soil Sci 169:295-309

Joergensen RG, Wichern F (2008) Quantitative assessment of the fungal contribution to microbial tissue in soil. Soil Biol Biochem 40:2977-2991

Kandeler E (1996) Ammonium, nitrate. In: Schinner F, Kandeler E, Öhlinger R, Margsin R (eds) Methods in soil biology. Springer, Berlin, pp 406-410

Keiblinger KM, Hall EK, Wanek W, Szukics U, Hämmerle I, Ellersdorfer G, Böck S, Strauss J, Sterflinger K, Richter A (2010) The effect of resource quantity and resource stoichiometry on microbial carbon use efficiency. FEMS Microbiol Ecol 73:430-440

Keiblinger KM, Schneider T, Roschitzki B, Schmid E, Eberl L, Hämmerle I, Zechmeister-Boltenstern S (2012) Effects of stoichiometry and temperature perturbations on beech leaf litter decomposition, enzyme activities and protein expression. Biogeosciences 9:4537-4551

Keyser P, Kirk TK, Zeikus JG (1978) Ligninolytic enzymesystem of phanerochaete-chrysosporium - synthesized in absence of lignin in response to nitrogen starvation. J Bacteriol 135:790-797

Kitzler B, Zechmeister-Boltenstern S, Holtermann C, Skiba U, Butterbach-Bah K (2006a) Controls over N2O, NOx and
CO2 fluxes in a calcareous mountain forest soil. Biogeosciences 3:383-395

Kitzler B, Zechmeister-Boltenstern S, Holtermann C, Skiba U, Butterbach-Bahl K (2006b) Nitrogen oxides emission from two beech forests subjected to different nitrogen loads. Biogeosciences 3:293-310

Lavelle P, Lattaud C, Trigo D, Barois I (1995) Mutualism and biodiversity in soils. Plant Soil 170:23-33

Leckie SE, Prescott CE, Grayston SJ, Neufeld JD, Mohn WW (2004) Comparison of chloroform fumigation-extraction, phospholipid fatty acid, and DNA methods to determine microbial biomass in forest humus. Soil Biol Biochem 36:529-532

Marstorp H (1996) Influence of soluble carbohydrates, free amino acids, and protein content on the decomposition of Lolium multiflorum shoots. Biol Fertil Soils 21:257-263

McMahon SK, Williams MA, Bottomley PJ, Myrold DD (2005) Dynamics of microbial communities during decomposition of carbon-13 labeled ryegrass fractions in soil. Soil Sci Soc Am J 69:1238-1247

Meentemeyer V (1978) Macroclimate and lignin control of litter decomposition rates. Ecology 59:465-472

Melillo JM, Aber JD, Muratore JF (1982) Nitrogen and lignin control of hardwood leaf litter decomposition dynamics. Ecology 63:621-626

Mille-Lindblom C, Tranvik LJ (2003) Antagonism between bacteria and fungi on decomposing aquatic plant litter. Microb Ecol 45:173-182

Moorhead DL, Sinsabaugh RL (2006) A theoretical model of litter decay and microbial interaction. Ecol Monogr 76:151-174

Mooshammer M, Wanek W, Schnecker J, Wild B, Leitner S, Hofhansl F, Blöchl A, Hämmerle I, Frank AH, Fuchslueger L, Keiblinger KM, Zechmeister-Boltenstern S, Richter A (2011) Stoichiometric controls of nitrogen and phosphorus cycling in decomposing beech leaf litter. Ecology 93:770782

Mungai NW, Motavalli PP (2006) Litter quality effects on soil carbon and nitrogen dynamics in temperate alley cropping systems. Appl Soil Ecol 31:32-42

Öhlinger R (1996) Biomass-C by fumigation-extraction technique. In: Schinner F, Kandeler E, Öhlinger R, Margsin R (eds) Methods in soil biology. Springer, Berlin, pp 54-56

Osono T (2007) Ecology of ligninolytic fungi associated with leaf litter decomposition. Ecol Res 22:955-974

Osono T, Takeda H (2006) Fungal decomposition of Abies needle and Betula leaf litter. Mycologia 98:172-179

Prescott CE (1995) Does nitrogen availability control rates of litter decomposition in forests. Plant Soil 169:83-88

Prescott CE (2005) Do rates of litter decomposition tell us anything we really need to know? Forest Ecology and Management 220:66-74

Prescott CE (2010) Litter decomposition: what controls it and how can we alter it to sequester more carbon in forest soils? Biogeochemistry 101:133-149

R_Development_Core_Team (2009) R: a language and environment for statistical computing. R Foundation for Statistical Computing, Vienna

Rousk J, Baath E (2007) Fungal and bacterial growth in soil with plant materials of different $\mathrm{C} / \mathrm{N}$ ratios. FEMS Microbiol Ecol 62:258-267 
Salamanca EF, Kaneko N, Katagiri S (1998) Effects of leaf litter mixtures on the decomposition of Quercus serrata and Pinus densiflora using field and laboratory microcosm methods. Ecol Eng 10:53-73

Salamanca EF, Raubuch M, Joergensen RG (2002) Relationships between soil microbial indices in secondary tropical forest soils. Appl Soil Ecol 21:211-219

Schaufler G, Kitzler B, Schindlbacher A, Skiba U, Sutton M, Zechmeister Boltenstern S (2010) Greenhouse gas emissions from European soils under different land use: effects of soil moisture and temperature. Eur J Soil Sci 61:683696

Schlief J, Mutz M (2007) Response of aquatic leaf associated microbial communities to elevated leachate DOC: a microcosm study. Int Rev Hydrobiol 92:146-155

Schneider T, Gerrits B, Gassmann R, Schmid E, Gessner MO, Richter A, Battin T, Eberl L, Riedel K (2010) Proteome analysis of fungal and bacterial involvement in leaf litter decomposition. Proteomics 10:1819-1830

Schneider T, Keiblinger KM, Schmid E, Sterflinger-Gleixner K, Ellersdorfer G, Roschitzki B, Richter A, Eberl L, Zechmeister-Boltenstern S, Riedel K (2012) Who is who in litter decomposition\&quest; metaproteomics reveals major microbial players and their biogeochemical functions. ISME J 6:1749-1762

Silveira ML, Reddy KR, Comerford NB (2011) Litter decomposition and soluble carbon, nitrogen, and phosphorus release in a forest ecosystem. Open J Soil Sci 1:86-96
Sinsabaugh RL, Hill BH, Shah JJF (2009) Ecoenzymatic stoichiometry of microbial organic nutrient acquisition in soil and sediment. Nature 462:795-798

Six JF, Thiet S, Batten R (2006) Bacterial and fungal contributions to carbon sequestration in agroecosystems. Soil Sci Soc Am J 70:555-569

Taylor BR, Parkinson D, Parsons WFJ (1989) Nitrogen and Lignin Content as Predictors of Litter Decay-Rates-a Microcosm Test. Ecology 70:97-104

Tempest D and Meers J (1973) Glutamate synthetase (GOGAT); a key enzyme in the assimilation of ammonia by prokaryotic organisms. The enzymes of glutamine metabolism. 167-182

Tscherko D, Hammesfahr U, Marx MC, Kandeler E (2004) Shifts in rhizosphere microbial communities and enzyme activity of Poa alpina across an alpine chronosequence. Soil Biol Biochem 36:1685-1698

van der Wal A, van Veen JA, Smant W, Boschker HT, Bloem J, Kardol P, de Boer W (2006) Fungal biomass development in a chronosequence of land abandonment. Soil Biol Biochem 38:51-60

White DC, Stair JO, Ringelberg DB (1996) Quantitative comparisons of in situ microbial biodiversity by signature biomarker analysis. J Ind Microbiol 17:185-196

Zelles L (1997) Phospholipid fatty acid profiles in selected members of soil microbial communities. Chemosphere 35:275-294

Zhang P, Tian XJ, He XB, Song FQ, Ren LL, Jiang P (2008) Effect of litter quality on its decomposition in broadleaf and coniferous forest. Eur J Soil Biol 44:392-399 